\title{
The Effects of Different Exercise Types on Hematological Parameters in Sedentary Women
}

\author{
Güner Çiçek \\ Correspondence: Güner ÇİÇEK, Faculty of Sport Sciences, Hitit University, Turkey. \\ Received: May 14, 2018 \\ doi:10.11114/jets.v6i8.3374 \\ Online Published: June 19, 2018 \\ URL: https://doi.org/10.11114/jets.v6i8.3374
}

\begin{abstract}
The purpose of this study is to investigate the effect of aerobic and strength exercises on hematological parameters in sedentary women. To achieve the purpose of this study, a total of 23 volunteers including aerobic exercise group (AE, n: 10), strength exercise group (SE, n:13) were selected as participants. Two different exercises were applied for 4 days a week, throughout 16 weeks, within 60 minutes for each exercise with the intensity of heart rate (HR) 60-70 percent. The HR was measured using a heart rate monitor for each subject.

The women's white blood cell (WBC), thrombocyte (PLT), red blood cell (RBC), hemoglobin (HGB), hematocrit (HCT) and mean corpuscular volume (MCV) were measured before and after exercise. For statistical analysis, the Wilcoxon signed-rank test was used for intra-group evaluations, and the Mann Whitney $U$ test was used for inter-group evaluations. After the exercise program, there were a meaningful decrease in the body weight and body mass index (BMI) the women in both intervention groups. In addition, in the hematological results of strength exercise group, some meaningful decreases were determined in the values of RBC, HGB, HCT and MCV ( $p<0.01)$. As a results, it was observed that regular aerobic and strength exercises can positively influence the body weight and BMI parameters of sedentary women. Along with this, a meaningful decrease has been found in the values of RBC, HGB, HCT and MCV of strength exercise group compared to aerobic exercise.
\end{abstract}

Keyword: exercise, sedentary woman, hematological parameters

\section{1-Introduction}

Blood is made up of an intracellular liquid (plasma) which has a major role of maintaining homeostasis (Isaac et al., 2013) and red blood cells, white blood cells, and platelets that are suspended in this liquid. The circulating blood volume constitutes about $7 \%$ of the total body weight. Approximately 55\% of the blood is plasma and the protein content is $7 \mathrm{~g} / \mathrm{dl}$ (appx. $4 \mathrm{~g} / \mathrm{dl}$ albumin and $3 \mathrm{~g} / \mathrm{dl}$ plasma globulins) (Berne et al., 2008). The basic function of the circulating blood is to provide $\mathrm{O}_{2}$ and nutrients to the tissues, and remove the carbon dioxide and waste products (Günay et al., 2008).

The blood volume and hemoglobin amount increase with exercise. As the blood volume increases together with the hemoglobin content, the hemoglobin content remains stable, or can even slightly decrease (Powell et al., 1987; Uzun, 2016). Regular exercise can affect the blood parameters (Astrand \& Rodalf, 1986). Thus the hematological parameters can change, depending on the type, intensity and duration of the exercise (Çakmakçı, 2009; İbiş et al., 2010). The hematological values can change during and after vigorous exercise, which can vary according to gender, age, environment or nutrition (Çakmakçı, 2009; Cengiz ve Çınar, 2014). Some researchers have found that some hematological parameters increase after regular exercises (Wardny et al. 2008; Koushi et al., 2013; Kantyka, et al., 2015; Gnanou et al., 2014; Ceylan et al., 2014; Duzova et al., 2016), whereas some researchers have indicated that there is no change (Spiropoulos and Trakada, 2003; Çakmakçı, 2009).

The purpose of this study is to evaluate the hematological parameters of sedentary women after long-term aerobic and strength exercises.

\section{Method}

\subsection{Participants}

Twenty-three healthy sedentary women participated voluntarily in this study. All selected participants were randomly divided into two groups as aerobic exercise group ( $\mathrm{AE}, \mathrm{n}=10$, age $33 \pm 2.7$ ), strength exercise group (CE, $\mathrm{n}=13$, age 


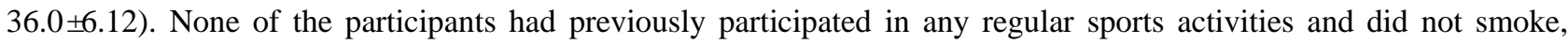
special diet program is not implemented or have any chronic disorders, heart disease, or respiratory infections. An informed consent form prepared according to the Helsinki Declaration was signed by the women.

\subsection{Exercise Intervention}

During the exercises, the heart rate (HR) of both groups was controlled by a portable pulsimeter (Polar) device. In order to determine the severity of exercise in accordance with the Karvonen Method, the target HRs of each subject were separately calculated as follows: Target HR $=[(220-$ AGE $)-$ RHR $]$ x $0.70+$ RHR (Goldberg et al. 1988).

\subsubsection{Aerobic Exercise Program}

The women were given aerobic-step exercise for 60 minutes for 4 days a week for 16 weeks according to their designated target HR levels. Warm-up exercises were done for 10 minutes, followed by 40 -minute basic aerobic-step exercises, and finally 10-minute cool-down exercises.

\subsubsection{Strength Exercise Program}

The women were given core for 60 minutes for 4 days a week for 16 weeks according to their designated target HR levels. Warm-up exercises were done for 10 minutes, followed by 40-minute basic core exercises included 3 sets/10 repetitions/set, 1-2min resting interval, (hip lifts with knee, crunches, side crunch, legs straight up crunches, half-up twists, push-ups on knees, plank leg lifts, squats, superman — opposite arm and leg extension, side lunge, left and right, bicycles) (Chabut, 2009) and 10 -minute cool-down exercises.

\subsection{Physical Tests}

The height of the women was measured using a steel Mescon brand tape in meters (m) with a precision of $1 \mathrm{~mm}$ with the women's bare feet standing flat on the ground, heels adjoining, knees tense, and body in the vertical position. The body weight measurement was measured in kilograms $(\mathrm{kg})$ on a scale with a precision of $0.01 \mathrm{~kg}$ provided that the women had bare feet and wore light clothes. The body mass index (BMI) formula (Body weight / Height ${ }^{2}$ ) was used to determine the body mass index.

\subsection{Hematological Parameters}

Subjects were warned about not to eat or drink anything after 22:00 pm one day before their blood samples were taken. Blood samples were taken in laboratory between 9:00-10:00 in the morning on an empty stomach. Hematological parameters including number of white blood cell (WBC), number of platelet (PLT), red blood cell (RBC), hemoglobin (HGB), hematocrit (HCT), mean corpuscular volume were taken as bases to hematological parameters and were determined by automatic cell analyzer (Beckman Coulter, USA).

\subsection{Statistical Analysis}

The SPSS 20.0 statistical package program was used in calculating the data. The descriptive statistics are given as $(\mathrm{X} \pm$ $\mathrm{Sd}$ in the text by calculating the arithmetic mean $(\mathrm{X})$ and standard deviation $(\mathrm{Sd})$ of the data. The normality test was carried out by using the Shapiro-Wilcoxon test, and non-parametric tests were applied. The Wilcoxon signed-rank test was used for intra-group evaluations and the Mann-Whitney U test was used for inter-group evaluations. In this study, $\mathrm{p}<0.05$ and $\mathrm{p}<0.01$ was regarded as the significance level.

\section{Results}

Table 1. Anthropometric data $(\mathrm{mean} \pm \mathrm{Sd})$

\begin{tabular}{lll}
\hline & AE $(\mathbf{n}=\mathbf{1 0})$ & SE $(\mathbf{n}=\mathbf{1 3})$ \\
\hline Age $($ years $)$ & $33 \pm 2.7$ & $36.0 \pm 6.12$ \\
Height $(\mathbf{c m})$ & $160.3 \pm 1.2$ & $162 \pm 2.3$ \\
Weight $(\mathbf{k g})$ & $73.40 \pm 8.75$ & $73.76 \pm 8.69$ \\
BMI $\left(\mathbf{k g} / \mathbf{m}^{\mathbf{2}}\right)$ & $28.67 \pm 3.28$ & $29.45 \pm 2.29$ \\
\hline
\end{tabular}


Table 2. Comparison of some hematological parameters of the groups before and after exercise

\begin{tabular}{|c|c|c|c|c|c|}
\hline \multirow[b]{2}{*}{ Variables } & \multicolumn{3}{|c|}{ Aerobic exercise $(n=10)$} & \multicolumn{2}{|c|}{ Strenght exercise $(n=13)$} \\
\hline & Exe. & $\mathrm{X} \pm \mathrm{Sd}$ & $\mathbf{p}$ & $X \pm S d$ & $\mathbf{p}$ \\
\hline Weight (kg) & $\begin{array}{l}\text { Pre } \\
\text { Post }\end{array}$ & $\begin{array}{l}73.40 \pm 8.75 \\
68.70 \pm 8.12\end{array}$ & $0.007 * *$ & $\begin{array}{l}73.76 \pm 8.69 \\
69.00 \pm 7.97\end{array}$ & $0.001 * *$ \\
\hline BMI $\left(\left(\mathrm{kg} / \mathrm{m}^{2}\right)\right.$ & $\begin{array}{l}\text { Pre } \\
\text { Post }\end{array}$ & $\begin{array}{l}28.67 \pm 3.28 \\
26.80 \pm 2.77\end{array}$ & $0.008 * *$ & $\begin{array}{l}29.45 \pm 2.29 \\
27.56 \pm 2.29\end{array}$ & $0.001 * *$ \\
\hline WBC(k/uL) & $\begin{array}{l}\text { Pre } \\
\text { Post }\end{array}$ & $\begin{array}{l}6.87 \pm 1.32 \\
6.77 \pm 1.54\end{array}$ & 0.906 & $\begin{array}{l}7.35 \pm 1.29 \\
7.27 \pm 1.07\end{array}$ & 0.754 \\
\hline $\operatorname{PLT}(\mathbf{k} / \mathbf{u L})$ & $\begin{array}{l}\text { Pre } \\
\text { Post }\end{array}$ & $\begin{array}{l}259.20 \pm 79.88 \\
262.00 \pm 64.07\end{array}$ & 0.767 & $\begin{array}{l}265.84 \pm 62.62 \\
254.84 \pm 60.33\end{array}$ & 0.152 \\
\hline $\mathbf{R B C}(\mathbf{m} / \mathbf{u L})$ & $\begin{array}{l}\text { Pre } \\
\text { Post }\end{array}$ & $\begin{array}{l}4.60 \pm 0.23 \\
4.38 \pm 0.20\end{array}$ & 0.053 & $\begin{array}{l}4.52 \pm 0.27 \\
4.34 \pm 0.26\end{array}$ & $0.003 * *$ \\
\hline HGB(g/dl) & $\begin{array}{l}\text { Pre } \\
\text { Post }\end{array}$ & $\begin{array}{l}12.25 \pm 1.52 \\
11.93 \pm 1.35\end{array}$ & 0.235 & $\begin{array}{l}12.60 \pm 1.19 \\
11.74 \pm 1.31\end{array}$ & $0.002 * *$ \\
\hline HCT(\%) & $\begin{array}{l}\text { Pre } \\
\text { Post }\end{array}$ & $\begin{array}{l}38.10 \pm 3.91 \\
36.58 \pm 3.25\end{array}$ & 0.110 & $\begin{array}{l}38.57 \pm 3.15 \\
35.99 \pm 3.46\end{array}$ & $0.001 * *$ \\
\hline $\operatorname{MCV}(\mathbf{f L})$ & $\begin{array}{l}\text { Pre } \\
\text { Post }\end{array}$ & $\begin{array}{l}82.78 \pm 7.12 \\
83.55 \pm 7.09\end{array}$ & 0.646 & $\begin{array}{l}85.27 \pm 6.73 \\
82.97 \pm 7.73\end{array}$ & $0.006 * *$ \\
\hline
\end{tabular}

$* p<0.05 ; * * p<0.01$

Note: BMI (Body mass index), WBC=white blood cells, PLT $=$ Thrombocyte Count, $\mathrm{RBC}=$ red blood cells, HGB= Hemoglobin, $\mathrm{HCT}=$ hematocrit, $\mathrm{MCV}=$ Mean corpuscular volume.

The comparison of the groups before and after exercise within themselves has revealed that there were a meaningful decrease in the body weight and body mass index (BMI) the women in both exercises groups $(\mathrm{p}<0.01)$. For the aerobic exercise (AE) group, it was determined that the HGB and HCT values were lower and the PLT and MCV values were higher. However, this result was not statistically significant ( $p>0.01)$. For the strength exercise (SE) group, it was found that the RBC, HGB, HCT, and MCV variables significantly decreased ( $\mathrm{p}<0.01$ ).

Table 3. The comparison of some hematological parameters of the groups before and after exercise

\begin{tabular}{|c|c|c|c|c|c|c|c|c|c|}
\hline \multirow{2}{*}{ Variables } & \multicolumn{4}{|c|}{ Pre exercises } & \multicolumn{5}{|c|}{ Post exercises } \\
\hline & Group & Min. & Max. & $\mathbf{X} \pm$ Sd & $\mathbf{P}$ & Min. & Max. & $\mathbf{X} \pm$ Sd & $\mathbf{P}$ \\
\hline \multirow[t]{2}{*}{ Weight (kg) } & $\mathbf{A E}$ & 62.0 & 92.0 & $73.40 \pm 8.75$ & \multirow{2}{*}{0.906} & 57.0 & 82.0 & $68.70 \pm 8.12$ & \multirow{2}{*}{0.860} \\
\hline & SE & 60.0 & 92.0 & $73.76 \pm 8.69$ & & 51.0 & 83.0 & $69.00 \pm 7.97$ & \\
\hline \multirow[t]{2}{*}{ BMI $\left(\mathrm{kg} / \mathrm{m}^{2}\right)$} & $\mathbf{A E}$ & 24.22 & 35.06 & $28.67 \pm 3.28$ & \multirow{2}{*}{0.639} & 22.27 & 31.25 & $26.80 \pm 2.77$ & \multirow{2}{*}{0.792} \\
\hline & SE & 24.5 & 34.13 & $29.45 \pm 2.29$ & & 21.79 & 31.22 & $27.56 \pm 2.29$ & \\
\hline WBC & $\mathbf{A E}$ & 4.90 & 8.90 & $6.87 \pm 1.32$ & \multirow{2}{*}{0.476} & 4.10 & 8.90 & $6.77 \pm 1.54$ & \multirow{2}{*}{0.420} \\
\hline$(\mathbf{k} / \mathbf{u L})$ & SE & 5.60 & 9.90 & $7.35 \pm 1.29$ & & 5.50 & 8.90 & $7.27 \pm 1.07$ & \\
\hline \multirow[t]{2}{*}{ PLT (k/uL) } & $\mathbf{A E}$ & 121.0 & 435.0 & $259.20 \pm 79.8$ & \multirow{2}{*}{0.535} & 128.0 & 364.0 & $262.00 \pm 64.07$ & \multirow{2}{*}{0.687} \\
\hline & SE & 140.0 & 362.0 & $265.84 \pm 62.62$ & & 145.0 & 348.0 & $254.84 \pm 60.33$ & \\
\hline \multirow[t]{2}{*}{$\mathbf{R B C}(\mathbf{m} / \mathbf{u L})$} & $\mathbf{A E}$ & 4.16 & 4.92 & $4.60 \pm 0.23$ & \multirow{2}{*}{0.226} & 4.13 & 4.83 & $4.38 \pm 0.20$ & \multirow{2}{*}{0.733} \\
\hline & SE & 4.16 & 5.23 & $4.52 \pm 0.27$ & & 3.95 & 4.98 & $4.34 \pm 0.26$ & \\
\hline \multirow[t]{2}{*}{ HGB (g/dl) } & $\mathbf{A E}$ & 9.30 & 14.20 & $12.25 \pm 1.52$ & \multirow{2}{*}{0.456} & 9.80 & 13.50 & $11.93 \pm 1.35$ & \multirow{2}{*}{0.780} \\
\hline & SE & 10.50 & 14.50 & $12.60 \pm 1.19$ & & 9.90 & 13.70 & $11.74 \pm 1.31$ & \\
\hline \multirow[t]{2}{*}{ HCT (\%) } & $\mathbf{A E}$ & 29.70 & 42.0 & $38.10 \pm 3.91$ & \multirow{2}{*}{0.951} & 31.20 & 40.10 & $36.58 \pm 3.25$ & \multirow{2}{*}{0.576} \\
\hline & SE & 32.0 & 44.20 & $38.57 \pm 3.15$ & & 31.0 & 41.10 & $35.99 \pm 3.46$ & \\
\hline \multirow[t]{2}{*}{ MCV (fL) } & $\mathbf{A E}$ & 71.50 & 95.0 & $82.78 \pm 7.12$ & \multirow{2}{*}{0.321} & 71.10 & 92.70 & $83.55 \pm 7.09$ & \multirow{2}{*}{0.852} \\
\hline & SE & 72.30 & 94.40 & $85.27 \pm 6.73$ & & 71.20 & 94.50 & $82.97 \pm 7.73$ & \\
\hline
\end{tabular}

$* p<0.05$

The evaluation of Table 3 suggests that the before and after exercise weight, BMI, WBC, PLT, RBC, HGB, HCT and MCV parameters are not significantly different between the two groups.

\section{Discussion}

In this study, sedentary women were given exercise for 16 weeks (aerobic and strength) in order to determine the positive effects of exercise on hematological parameters.

Regular exercise improves both the physical and mental strength of a person. Many studies indicate that long-term aerobic, aerobic-step and strength exercises positively influence the body weight and BMI values (Donnelly et al., 2003; Harbili et al., 2005; Haksel et al., 2007; Gönülateş et al., 2010; Chaudhary et al. 2010; Ossanloo et al., 2012; Morencos et al., 2012). The findings of this study indicate that the 16-week exercise program (including aerobic and strength exercises) has significantly decreased the body weights and BMI of women in both groups. Our findings are compatible with the literature, which suggests that long-term exercises positively affect body weight and BMI. 
As blood parameters can influence the type and intensity of the exercise, it is known that exercise can affect the blood parameters (Astrand \& Rodalf, 1986; Ceylan et al., 2014; Bezci and Kaya, 2010). It is well known that physical exercise and sports affect the hemoglobin ( $\mathrm{Hb}$ ) concentrations (Fujitsuka et al., 2004). Fujitsuka et al. (2004) have found that the HGB values decreased after a 12-week long ranger training program.

Sazvar et al., (2013) have found that during an 8-week aerobic morning exercise the number of red blood cells, hemoglobin levels, and hemotocrit percentage increased, number of platelets decreased significantly. Ceylan et al., (2014) have reported that HGB significantly more decreased in aerobic dance group as compared with step dance group and and they reported this reduction may be associated with malnutrition rather than exercise. İbiş et al., (2008) noticed no significant differences in the hematological values after the aerobic exercise, it was then determined that there were significant increases in the, HCT, HGB, WBC values after the anaerobic exercise and significant decreases in these values after 24 hours. Another study have found have found there are positive changes in hematological values among sedentary females after the 8-week core exercise program but these changes are not significant in others except for RBC (Cengiz and Çınar, 2014).

Yeh et al. (2006) have evaluated the blood samples of 14 male and 23 female athletes, who are doing regular exercise for 12 weeks, before and after an exercise period of 12 weeks. They did not find a significant change in the WBC and RBC levels (p <0.001). Another similar study by Ümit et al., (2004) has studied the RBC levels of 9 sedentary and 9 athletes before and after a two-week exercise program. They did not find a significant change in the RBC values. The reason for this lack of a significant change can be related to the intensity of the exercise (Bezci and Kaya, 2010).

Gallagher et al. (2000) have conducted an 8-week-long aerobic exercise program among adults (aged 18-29, normal diet and diet with supplements). They have found a significant increase of HGB levels in both groups. In contrast, Mashiko et al. (2004) indicate that a 20-day exercise program did not significantly change the HCT values of the 25 athlete subjects. Pouramir et al. (2004) have studied the blood samples of 35 male gymnasts before and after a 10-week exercise program. They did not find a significant change in the MCV and erythrocyte levels ( $p>0.05)$. It is assumed that this is due to the characteristic decrease of HBG and HCT levels of the athletes that intensely exercise, a condition that is called "athlete's anemia" (Londeann et al., 1978; Thorner et al., 1933).

Some researchers claim that the HCT values were lower among athletes compared to sedentary individuals (Ernst, 1987; Sawka et al., 2000). Some researchers associate this condition with the exercise-associated erythrocyte catabolism (Kurz, 1948; Martin and Kilian, 1959). The increase in plasma viscosity that can occur during exercise (Rand et al., 1970) has been shown to be associated with the changes in erythrocyte deformability and the increased temperature (El-Sayed et al., 2005.) Yoshimura et al., (1980) claim that these changes may be linked to the duration and type of the exercise.

Our findings indicate that, for the aerobic exercise group, the HGB and HCT values decreased and the PLT and MCV values increased at the end of an exercise period of 16 weeks, but these findings were not statistically significant. In the strength exercise group, the RBC, HGB, HCT and MCV variables significantly decreased $(p<0.01)$. This decrease is due to the increased requirement of muscular exertion in the SE group which in turn increases blood viscosity, decrease deformability and increase body temperature. Another cause of exercise-associated anemia is the inadequate intake of protein (Yoshimura et al., 1980) and iron deficiency (Hunding et al., 1981). In our study, neither of the study groups received protein or iron supplements during the exercise period. Accordingly, it can be said that the nutritional deficiency will be more prominent in the strength exercise group compared to the aerobic exercise group, which can decrease the hematological parameters.

It was observed that regular aerobic and strength exercises can positively influence the body weight and BMI parameters of sedentary women. It was determined that strength exercises significantly decrease some hematological parameters.

\section{References}

Astrand, P. O., \& Rodalf, K. (1986). Textbook of Work Physiology Physiological Bases of Exercise. New York: McGraw-Hill Book Company

Berne, R. M., Levy, M. N., Koeppen, B. M., \& Stanton, B. A. (2008). Physiology, Türk Fizyolojik Bilimler Derneği (Fizyoloji). 5. Baskı Öncü Basımevi Yayınevi: mosby. 267.

Bezci, Ş., \& Kaya, Y. (2010). The analyze of hematological parameters of elite women taekwondoers before and after training. Pamukkale J. Sport Sci, 1(2), 1-16.

Çakmakçı, E. (2009). Erkek Taekwondocularda Kamp Döneminin Bazı Hematolojik Parametreler Üzerine Etkileri. Niğde Üniversitesi Beden Ĕgitimi ve Spor Bilimleri Dergisi, 3(1), 21-29. 
Cengiz, Ş. Ş., \& Çinar, V. (2014). The Effect of 8-Week Core Exercises on Some Hematological Parameters in Sedentary Females. Turkish Journal of Scientific Research, 1(1), 1-5.

Ceylan, H. İ., Babayiğit, İ. G., \& Saygın, Ö. (2014). Examining of the effects of aerobic dance and step dance exercises on some hematological parameters and blood lipids. International Journal of Human Sciences, 11(2), 980-991.

Chabut, L. (2009). Core Strength for Dummies. Copyright by Wiley Publishing, Inc., Indianapolis, Indiana, 66-101.

Chaudhary, S., Kang, M. K., \& Sandhu, J. S. (2010). The effects of aerobic versus resistance training on cardiovascular fitness in obese sedentary females. Asian J. Sports Med.,1(4), 177-184.

Donnelly, J. E., Hill, J. O, Jacobsen, D. J., Potteiger, J, Sullivan, D. K., Johnson, S. L., ... Washburn, R. A. (2003). Effects of a 16-month randomized controlled exercise trial on body weight and composition in young, overweight men and women: the Midwest Exercise Trial. Arch. Intern. Med., 163(11), 1343-1350.

Duzova, H., Karakoc, Y., Gullu, E., Gullu, A., Koksal, B., \& Esen, B. (2016). The acute effects of single football match on whole blood viscosity and hematological variables in female soccer players. Biomedical Research, 27(4), 1423-1425.

El-Sayed M. S., Ali, N., \& El-Sayed, A. Z. (2005). Haemorheology in exercise and training. Sports Med., 35, 649-670.

Ernst, E. (1987). Influence of regular physical activity on blood rheology. Eur. Heart J., 1(8), 59-62.

Fujitsuka, S., Koike, Y., Isozaki, A., \& Nomura, Y. (2005). Effect of 12 weeks of strenuous physical training on hematological changes. Military medicine, 170(7), 590-594.

Gallagher, P. M., Carrithers, J. A., Godard, M. P., Schulze, K. E., \& Trappe, S. W. (2000). $\beta$-Hydroxy- $\beta$-Methylbutyrate İngestion, Part II: Effects on Hematology, Hepatic and Renal Function. Med. Sci. Sports Ex., 32(12), 2116-2119.

Gnanou, J., Caszo, B., Khalin, I., Leong, S., Knight, V. F., \& Bidin, M. Z. B. (2014). The effect of 6-weeks military training on blood hematological parameters in untrained recruits in a military university. Medicine Science, 3(3), 1479-1490.

Goldberg, L., Elliot, D. L., \& Kuehl, K. S. (1988). Assessment of exercise intensity formulas by use of ventilatory threshold. Chest, 94(1), 95-98.

Gönülateş, S., Saygin, O., \& Babayigit, I. G. (2010). Düzenli Yürüyüş Programının 40-50 Yaşları Arası Bayanlarda Sağlık İlişkili Fiziksel Uygunluk Unsurları ve Kan Lipidleri Üzerine Etkisi. Uluslararası İnsan Bilimleri Dergisi, 7(2), 960-970.

Günay, M., Şıktar, E., Şıktar, E., \& Yazıcı, M. (2008). Egzersiz ve Kalp. Ankara, Gazi Kitabevi, 202-203.

Harbili, S., Özergin, U., Harbili, E., \& Akkuş, H. (2005). Kuvvet Antrenmanının Vücut Kompozisyonu ve Bazı Hormonlar Üzerine Etkisi. Spor Bilimleri Dergisi Hacettepe J. of Sport Sciences, 16(2), 64-76.

Haskell ,W. L., Lee, I. M., Pate, R. R., Powell, K. E., Blair, S. N., Franklin, B. A., ... Bauman, A. (2007). Physical activity and public health. Updated recommendation for adults from the American College of Sports Medicine and the American Heart Association. Circulation, 116(9), 1081-1093.

Hunding, A., Jordal, R., \& Paulev, P. E. (1981). Runner's anemia and iron deficiency. Acta Med. Scand, 209, 315-318.

İbiş, S., Hazar, S., \& Gökdemir, K. (2010). Aerobik ve anaerobik egzersizlerin hematolojik parametrelere akut etkisi. Uluslararasi Insan Bilimleri Dergisi, 7(1), 71-81.

Isaac, L. J., Abah, G., Akpan, B., \& Ekaette, I. U. (2013). Haematological properties of different breeds and sexes of rabbits. Proceedings of the 18th Annual Conference of Animal Science Association of Nigeria. 24-27.

Kantyka, J., Herman, D., Roczniok, R., \& Kuba, L. (2015). Effects of aqua aerobics on body composition, body mass, lipid profile, and blood count in middle-aged sedentary women. Human Movement, 16(1), 9-14.

Koushi, M. H., Mollanovruzib, A., \& Rashidlamirc, A. (2013). The Effect of wrestling exercise inmorning and afternoon on some hematological indices. International Journal of Applied Exercise Physiology, 2(1), 11-17.

Kurtz, A., Zapf, J., Eckardt, K. U., Clemons, G., Froesch, E. R., \& Bauer, C. (1988). Insulin-like growth factor I stimulates erythropoiesis in hypophysectomized rats. Proc. Natl. Acad. Sci. U.S.A. 85, 7825-7829.

Londeann, R. (1978). Low hematocrits during basic training athletes anemia. Nenld. J. Med., 299, 1191-1192.

Martin, H., \& Kilian, P. (1959). [March hemoglobinuria (Studies on the mechanism of hemolysis and review of the literature)]. Folia Haematol, 4, 92-117.

Mashiko, T., Umeda, T., Nakaji, S., \& Sugawara, K. (2004).Effects of exercise on the physical condition ofcollege 
rugby players during summer training camp, Br. J. Sports Med., 38(2), 186-190.

Morencos, E., Romero, B., Peinado, A. B., González-Gross, M., Fernández, C., Gómez-Candela, C., \& Benito, P. J. (2012). Effects of dietary restriction combined with different exercise programs or physical activity recommendations on blood lipids in overweight adults Nutr Hosp, 27(6):1916-1927.

Ossanloo, P., Zafari, A., \& Najar, L. (2012). The Effects of Combined Training (Aerobic Dance, Step Exercise and Resistance Training) on Cardio Vascular Disease Risk Factors in Sedentary Females. Annals of Biological Research, 3(7):3652-3656.

Pouramir, M., Haghshenas, O., \& Sorkhi, H. (2004). Effects of gymnastic exercise on the body iron status and hematologic profile. Iran J. Med. Sci., 29(3), 140-141.

Powell, K. E., Thompson, P. D., Caspersen, C. J., \& Kendrick, J. S. (1987). Physical activity and the incidence of coronary heart disease. Annual review of public health, 8(1), 253-287.

Rand, P. W., Barker, N., \& Lacombe, E. (1970). Effects of plasma viscosity and aggregation on whole-blood viscosity. Am. J. Physiol. 218, 681-688.

Sawka, M. N., Convertino, V. A., Eichner, E. R., Schnieder, S. M., \& Young, A. J. (2000). Blood volume: importance and adaptations to exercise training, environmental stresses, and trauma/sickness. Med. Sci. Sports Exerc., 32, $332-348$.

Sazvar, A., Mohammadi, M., Nazem, F., \& Farahpour, N. (2013). The effect of morning aerobic exercise on some hematological parameters in young, active males. Iranian Journal of Health and Physical activity, 4(1), 23-28.

Spiropoulos, K., \& Trakada, G. (2003). Hematologic and Biochemical Laboratory Parameters Before and After A Marathon Race. Lung, 181(2), 89-95.

Thorner, W. (1993). Quoted by srein hus AH. Choronic effects of exercise. Physiol. Rew., 13(24), 622.

Ümit, K. S., Yalçın, O., Gündüz, F., Kuru, O., Herbert, J. M., \& Baskurt, O. K. (2004). Effect of antioxidant vitamin treatment on the time course of hematological and hemorheological alterations after an exhausting exercise episode in human subjects, Appl. Physiol., 98, 1272-1279.

Uzun, M. (2016). Kardiyovasküler Sistem ve Egzersiz. Journal of Cardiovascular Nursing, 7(Sup 2), 48-53.

Wardyn, G. G., Rennard, S. I., Brusnahan, S. K., McGuire, T. R., Carlson, M. L., Smith, L. M., ... Sharp, J. G. (2008). Effects of exercise on hematological parameters, circulating side population cells, and cytokines. Experimental Hematology, 36(2), 216-223.

Yeh, S. H., Chuang, H., Lin, L. W., Hsiao, C. Y., \& Eng, H. L. (2006). Regular tai chi chuan exercise enhances functional mobility and cd4cd25 regulatory t cells, British Journal of Sports Medicine, 40, 239-243.

Yoshimura, H., Inoue, T., Yamada, T., \& Shiraki, K. (1980). Anemia during hard physical training (sports anemia) and its causal mechanism with special reference to protein nutrition. World Rev. Nutr. Diet., 35, 1-86.

\section{Copyrights}

Copyright for this article is retained by the author(s), with first publication rights granted to the journal.

This is an open-access article distributed under the terms and conditions of the Creative Commons Attribution license which permits unrestricted use, distribution, and reproduction in any medium, provided the original work is properly cited. 